\title{
Fine structure of the sheep oocyte during antral follicle development
}

\author{
D. G. Cran, R. M. Moor and Mary F. Hay* \\ Agricultural Research Council Institute of Animal Physiology, Animal Research Station, \\ 307 Huntingdon Road, Cambridge, CB3 OJQ, U.K.
}

\begin{abstract}
Summary. The structure and distribution of organelles within oocytes of developing antral follicles were studied qualitatively and quantitatively. In the smallest category of follicle $(0.2-0.4 \mathrm{~mm}$ diam.) the Golgi was present in a peripheral position, the endoplasmic reticulum was distended and mitochondria were intimately associated with it. Processes from surrounding cumulus cells were in contact with the oolemma which was thrown up into slender villi, increasing the oocyte surface area 5 -fold. In these and all subsequent follicles the oocyte cytoplasm contained numerous $30 \mathrm{~nm}$ particles or vesicles. As the follicles grew to about $2.0 \mathrm{~mm}$ the mitochondria became located in a peripheral band, interior to which were numerous large vesicles, and the villi became shorter and thicker. In follicles $>2.0 \mathrm{~mm}$ the mitochondrial band was largely dispersed and cortical granules rested close to the oolemma. Little structural change was then observed until late oestrus. In oocytes from preovulatory follicles at this stage an internal dense zone was formed in the zona pellucida. Most of the cumulus cell processes degenerated and most mitochondria assumed a hooded appearance.
\end{abstract}

\section{Introduction}

The capacity of sheep oocytes to develop to full physiological maturation in vitro differs according to the stage of growth and the class of follicle in which they are situated (Moor \& Warnes, 1978). To provide a structural basis for the evaluation of such oocytes it is necessary to have a detailed knowledge of their fine structure at different stages of hormonal development in vivo.

It is the purpose of this paper to describe and attempt to quantify the structural changes that occur in sheep oocytes as the follicle progresses from the early stages of antral development through to maximal development immediately before ovulation.

\section{Materials and Methods}

Follicles were obtained both during the luteal phase and at oestrus from mature Welsh Mountain ewes. Oocytes from non-atretic follicles in the luteal phase of the cycle with diameters ranging from 0.2 to $7.0 \mathrm{~mm}$ were examined. For ease of classification these were divided by diameter into the categories of $0.2-0.4 \mathrm{~mm}$ (5 follicles); $0.5-0.9 \mathrm{~mm}(\mathrm{~N}=3) ; 1.0-1.9 \mathrm{~mm}(\mathrm{~N}=3)$; 2.0-3.0 mm $(\mathrm{N}=4)$; and $5.0-7.0 \mathrm{~mm}(\mathrm{~N}=4)$. In addition, oocytes from the largest non-

- Deceased. 
atretic follicles of oestrous sheep were obtained at the onset of oestrus $(\mathrm{N}=3)$; at mid-oestrus, i.e. $12 \mathrm{~h}$ after onset, $(\mathrm{N}=2)$; and immediately before ovulation, i.e. $24 \mathrm{~h}$ after onset $(\mathrm{N}=6)$. The oocyte and cumulus were always sectioned in a plane perpendicular to the underlying thecal tissue. To obtain information on the precise timing of the early nuclear changes, non-atretic follicles $(3 \cdot 5-5 \cdot 5 \mathrm{~mm}$ diameter) were cultured with gonadotrophins as described previously (Moor \& Trounson, 1977). After 9, 12 or $15 \mathrm{~h}$ oocytes were processed for examination as $1 \mu \mathrm{m}$ sections or as whole mounts stained with orcein (Sanderson \& Stewart, 1961).

Ovaries were removed under pentobarbitone and fluothane anaesthesia and follicles over 0.4 mm were rapidly dissected out as described by Moor, Hay, McIntosh \& Caldwell (1973). Only those follicles which were judged to be non-atretic (Moor, Hay, Dott \& Cran, 1978) were retained. Follicles of $<0.4 \mathrm{~mm}$ diameter were obtained from small cubes of ovarian cortex. Follicles were immersed in $4 \%$ glutaraldehyde in $0.2 \mathrm{M}$-collidine buffer $(\mathrm{pH} \mathrm{7.2)}$ and for those with a diameter $>0.4 \mathrm{~mm}$, the region of the wall bearing the cumulus was removed with a razor blade. The samples were subsequently processed for electron microscopy as described by Hay, Cran \& Moor (1976). Thick sections $(1 \mu \mathrm{m})$ for light microscopy were stained with $1 \%$ toluidine blue in $1 \%$ borax.

In serial sections of ovaries embedded in paraffin wax the diameters of oocytes were measured with the light microscope in 10 primordial, 10 primary and 21 secondary follicles and in 14 antral follicles ranging in size from 0.4 to $2.5 \mathrm{~mm}$.

Counts of organelles were made from oocytes which had been cut approximately in half to minimise bias due to tangential sectioning. Counts were made within at least three oocytes and at two levels for each stage. A grid consisting of $1 \mathrm{~cm}$ squares was placed over low magnification micrographs (4800 or 7500 final magnification). A base line with a length equivalent to $25 \mu \mathrm{m}$ was placed on the oolemma and counts were made of organelles falling within the grid squares to about $60 \mu \mathrm{m}$ from the oocyte surface. Approximately one third of the section of each oocyte was covered in this manner and counts were normalized to $10 \mu \mathrm{m}^{2}$ and plotted as a function of distance from the surface (Text-fig. 3).

On many of the same oocytes from which the above numerical data were obtained a quantitative estimate was made of the factor by which the microvilli increased the surface area of the oocyte beyond that of a smooth sphere of the same diameter (Dick, Dick \& Bradbury, 1970).

\section{Results}

\section{Follicles of $0.2-0.4 \mathrm{~mm}$ diameter}

The size of the oocyte increased rapidly in growing preantral follicles and reached its maximal diameter $(\sim 110 \mu \mathrm{m})$ at about the time of antrum formation (Text-fig. 1). Morphometric analyses in this paper were carried out on oocytes from antral follicles, and observed changes in the number and distribution of organelles could not therefore be accounted for by changes in oocyte size.

The membrane of oocytes in small antral follicles was characterized by numerous slender villi (Pl. 2, Fig. 6) which increased the surface area about 5-fold over that of a smooth sphere of the same dimensions (Text-fig. 2). Thick processes from the surrounding cumulus cells made contact with the oolemma by desmosome-like junctions (Pl. 1, Fig. 5).

The oocyte cytoplasm was characterized by scattered mitochondria with associated endoplasmic reticulum (Text-fig. 3; P1. 1, Fig. 1; Pl. 2, Fig. 6). The endoplasmic reticulum was distended, largely smooth and its irregular profile suggested that much of it was interconnected. The Golgi was segmented, located towards the cell periphery and composed of small stacks of cisternae which were associated with numerous vesicles. Many small particles or vesicles about $30 \mathrm{~nm}$ in diameter with a dense rim and a lighter core were found in oocytes from this and all 


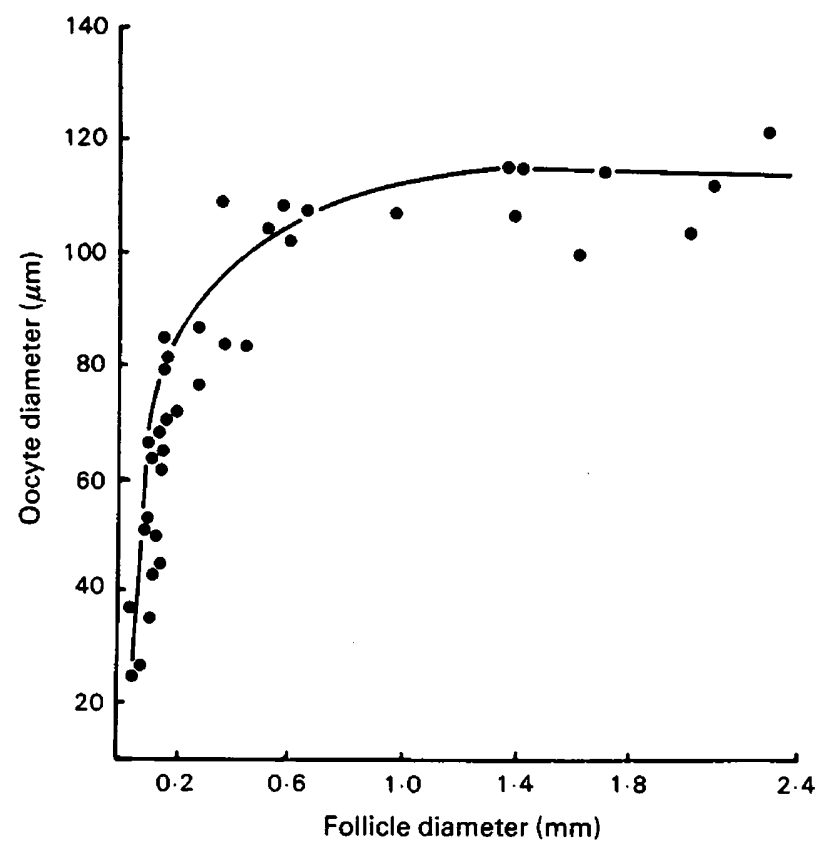

Text-fig. 1. Change in oocyte diameter with increased follicle size in sheep.

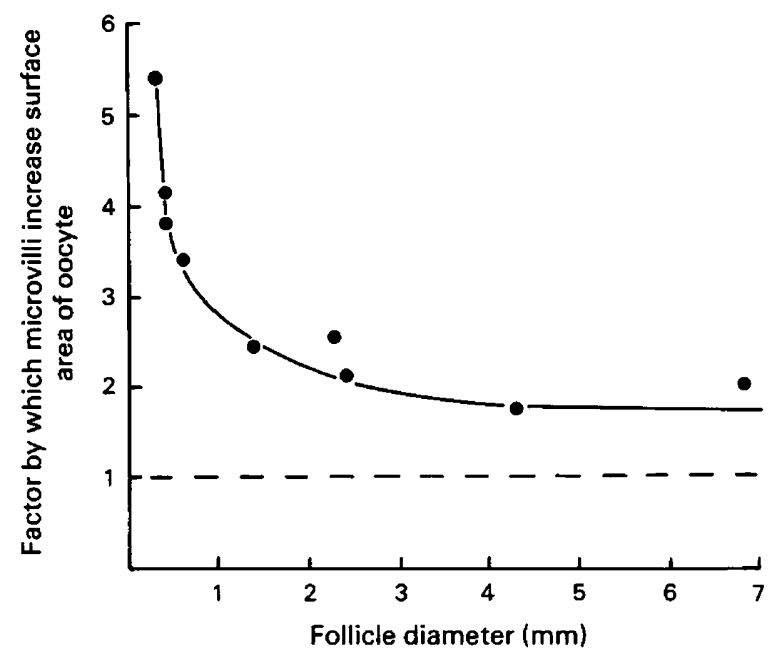

Text-fig. 2. The factor by which the microvilli increase the oocyte surface area beyond that of a smooth sphere plotted against follicle diameter. Each point represents one oocyte and the broken horizontal line represents the area of a smooth sphere of the same dimension.

subsequent sizes of antral follicles (P1 1, Fig. 4). These differed from the very limited number of ribosomes which were uniformly dense and occurred in small rosettes. The cortical granules which first appeared in oocytes from small antral follicles were randomly distributed (Text-fig. 3), about $0.3 \mu \mathrm{m}$ in diameter and comprised a central dense flocculent core and a zone of lesser density under the bounding membrane. Large membrane-bound vesicles, often with distorted membranes, were occasionally observed but showed no preferential distribution (Text-fig. 3). The nucleus was in a peripheral position with only a thin rim of cytoplasm separating it from the plasma membrane. 
Follicles of $0.5-0.9$ and $1.0-1.9 \mathrm{~mm}$ diameter

With increasing follicle size oocyte membrane surface area decreased (Text-fig. 2) because of the progressive shortening and thickening of the slender microvilli which tended to lie parallel with the oocyte surface (Pl. 2, Fig. 7). Often extensive areas without surface projections were present. Numerous processes from cumulus cells contacted the oolemma and occasionally penetrated up to $1.0 \mu \mathrm{m}$ into the cytoplasm (Pl. 1, Fig. 5). The cytoplasm in the region of contact was characterized by local densities on either side of the adjacent membranes. A clear shift of mitochondria into a peripheral band about $30 \mu \mathrm{m}$ in depth occurred in oocytes from these follicle

\section{PLATE 1}

Fig. 1. Light micrograph of oocyte from a follicle $0.4 \mathrm{~mm}$ in diameter. The dictyate nucleus is surrounded by an organelle-free area external to which are randomly distributed mitochondria. $\times 520$.

Fig. 2. Oocyte from a follicle $1.4 \mathrm{~mm}$ in diameter. The mitochondria are located almost entirely in a peripheral position with the interior being filled with vesicles. Note the presence of cumulus cell processes penetrating the zona pellucida. $\times 620$.

Fig. 3. Oocyte from a preovulatory follicle of a sheep at late oestrus. The mitochondria are more dispersed than those in Fig. 2. $\times 520$.

Fig. 4. Part of the cytoplasm of an oocyte $1.0 \mathrm{~mm}$ in diameter. Numerous small particles or vesicles are present (arrows). A dense mass of vesicles and filamentous material is visible at the bottom of the figure. $\times 25000$.

Fig. 5. Detail of a junction (J) between a cumulus cell process and the oolemma. The junction lies at the base of a channel from the oocyte surface. Desmosome-like junctions characterized by localized cytoplasmic densities (arrows) on either side of the adjacent membranes are present. Z, zona. $\times 38000$.

\section{PLATE 2}

Fig. 6. Tangential section of an oocyte from a follicle $0.3 \mathrm{~mm}$ in diameter. Numerous slender microvilli project from the oocyte surface into the zona pellucida $(Z)$. The mitochondria (arrows) are randomly arranged and are associated with dilated elements of endoplasmic reticulum (ER). The Golgi $(G)$ is located at the periphery of the cell. $\times 2400$.

Fig. 7. Oocyte from a follicle $1.5 \mathrm{~mm}$ in diameter, showing the mitochondrial band and the demarcation between it and the zone of large vesicles. Many of the vesicles have profiles suggestive of fusion or budding (B). The surface villi are thicker than in smaller follicles (see Fig. 6). Junctions with cumulus cells are present (arrows). A large aggregation of particles or vesicles (A) is also present. $\times 3800$.

\section{PLATE 3}

Fig. 8. Oocyte from a follicle $4.5 \mathrm{~mm}$ in diameter. Cortical granules (C) are present near the oolemma. The mitochondria (M) have maintained their relationship with the endoplasmic reticulum. A large aggregate of vesicles (A) is visible at the top of the figure. $\times 5700$.

Fig. 9. Part of an oocyte from a preovulatory follicle of a ewe at the onset of oestrus. A cumulus cell process is surrounded by small vesicles. Note the position of the cortical granules (C). $\times 16000$.

Fig. 10. Oocyte from a preovulatory follicle of a ewe $24 \mathrm{~h}$ after the onset of oestrus. A dense layer (D) is present in the zona pellucida close to the oolemma. Within it are degenerating remains of cumulus cell processes (P). The cortical granules (arrows) lie immediately adjacent to the oolemma. $\times 35000$.

Fig. 11. Oocyte as in Fig. 10. Hooded mitochondria with associated elements of endoplasmic reticulum are present. Note the position of the cortical granules (arrows). $\times 14000$. 


\section{PLATE 1}

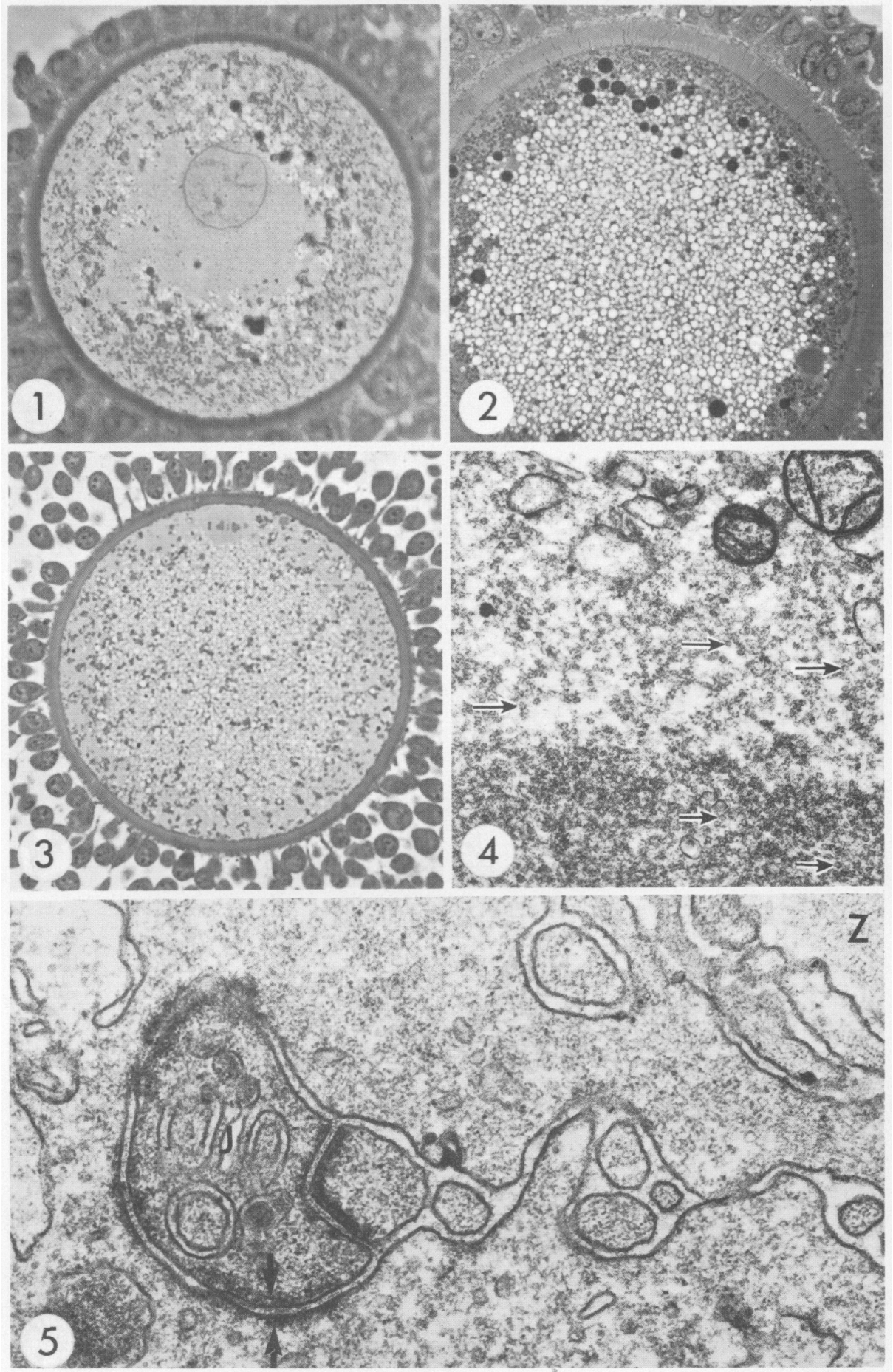

(Facing p. 128) 
PLATE 2
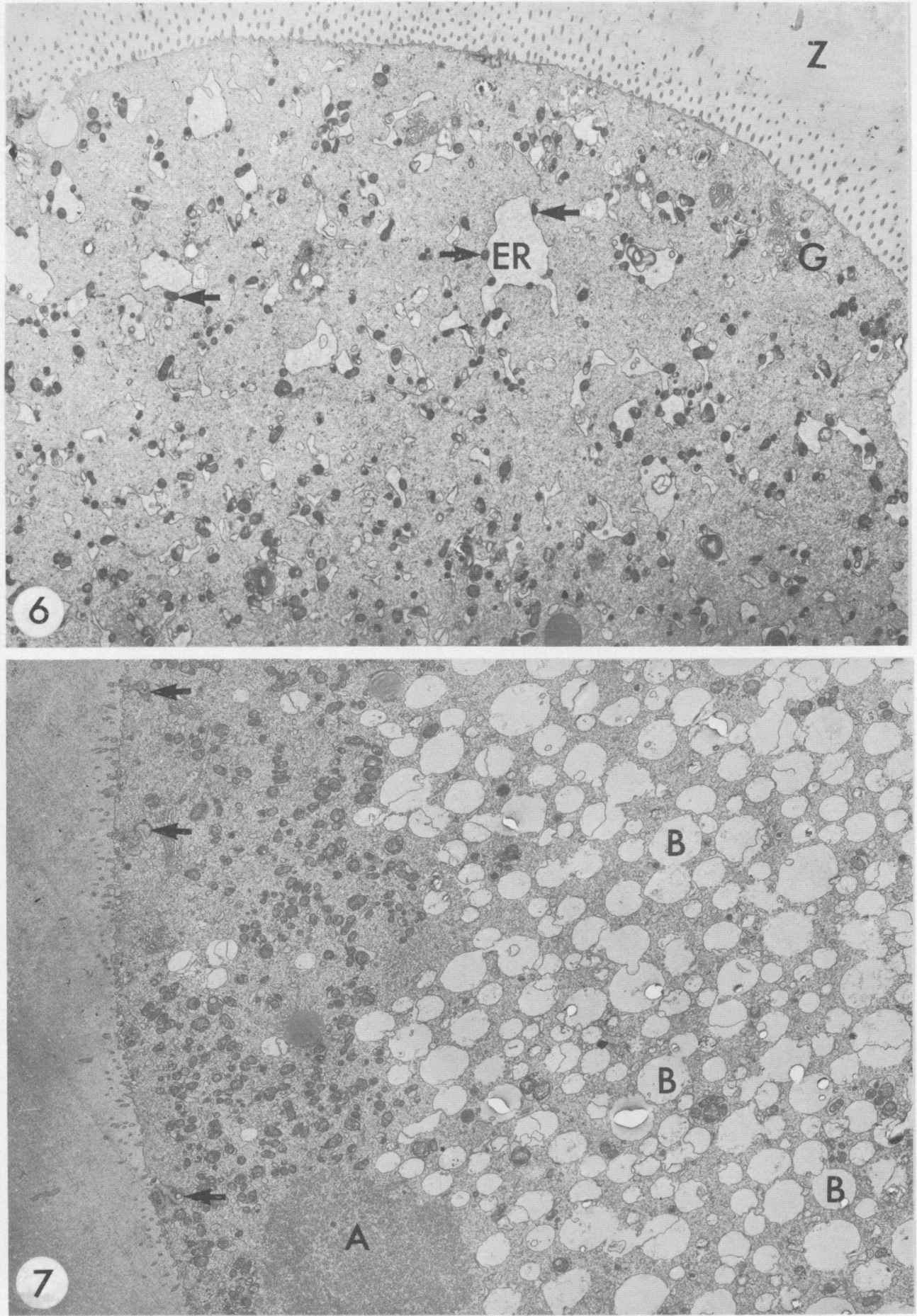
PLATE 3
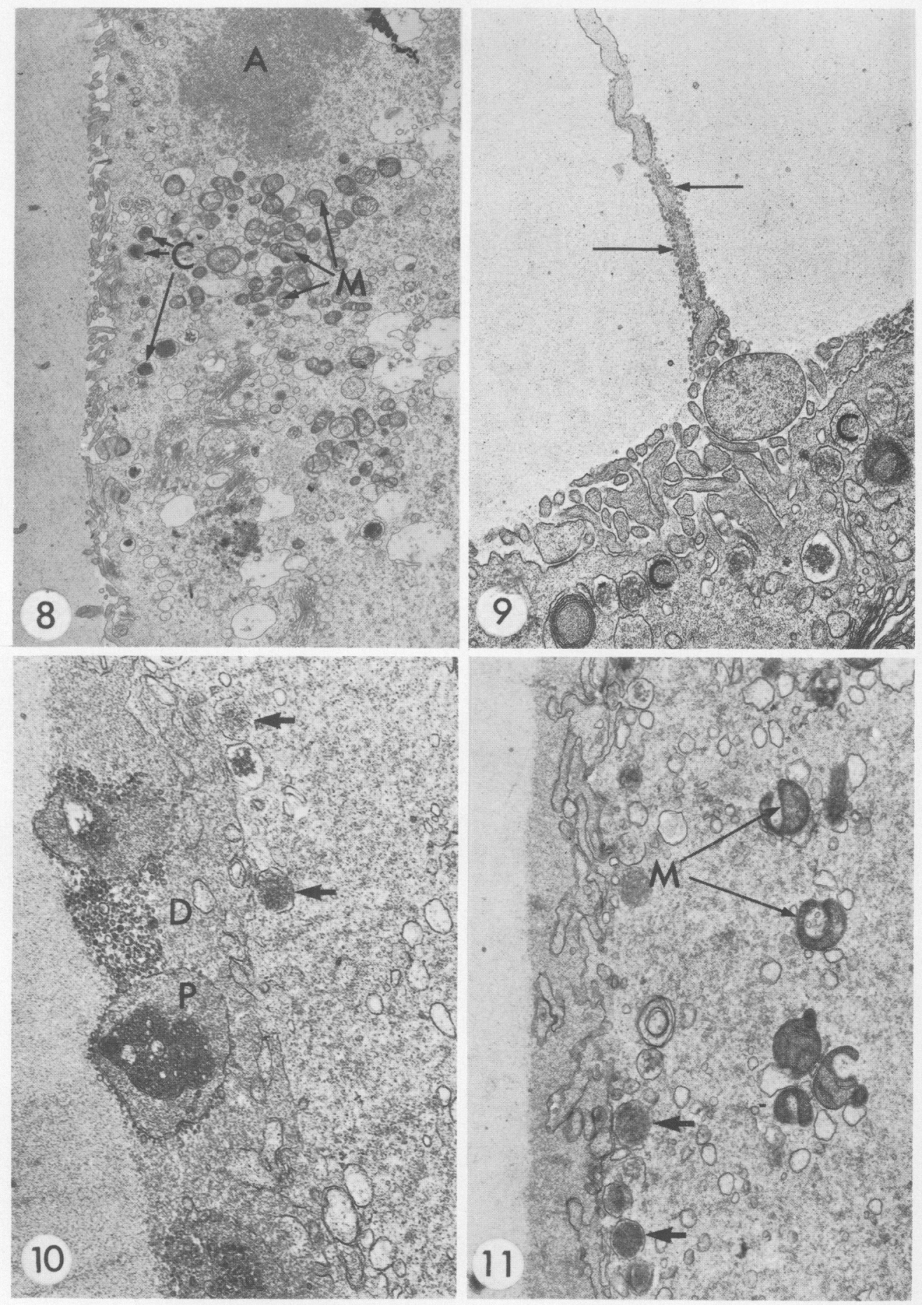
categories (Text-fig. 3; Pl. 1, Fig. 2; Pl. 2, Fig. 7). The mitochondria remained similar in size and morphological appearance, and retained their close association with the endoplasmic reticulum which was no longer markedly dilated. The large membrane-bound vesicles increased in number and became located towards the centre of the oocyte (Text-fig. 3; Pl. 1, Fig. 2). These vesicles varied considerably in size, had occasional flocculent contents, and numerous smaller vesicular elements were present among them. Profiles suggestive of fusion or budding were observed (PI. 2, Fig. 7), but the general lack of membrane integrity made this interpretation equivocal. The distribution of cortical granules remained the same as in the smaller follicles (Text-fig. 3). Occasional large aggregates of $30 \mathrm{~nm}$ particles with filamentous material were observed (Pl. 1, Fig. 4; Pl. 2, Fig. 7). These generally had a diameter of about $3 \mu \mathrm{m}$ but were sometimes larger with masses up to $8.0 \mu \mathrm{m}$ diameter.

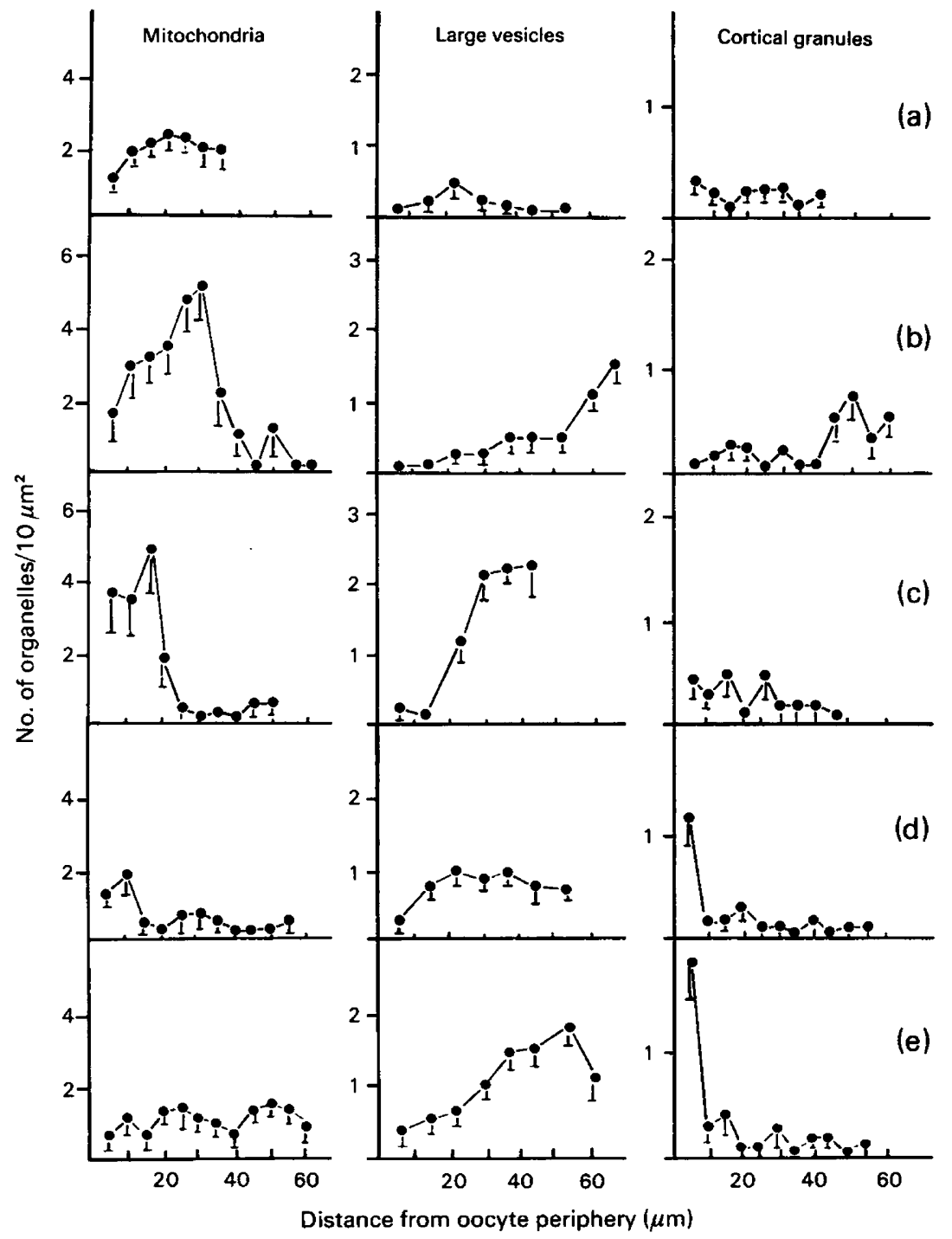

Text-fig. 3. Distribution of mitochondria, large vesicles and cortical granules in oocytes (a) 0.2 $0.4 \mathrm{~mm}$, (b) $0.5-0.9 \mathrm{~mm}$, (c) $1.0-1.9 \mathrm{~mm}$, and (d) $2.0-3.0 \mathrm{~mm}$ in diameter and (e) from preovulatory follicles from sheep $24 \mathrm{~h}$ after onset of oestrus. 
Follicles of 2.0-3.0 mm diameter and the largest follicle up to mid-oestrus

With one exception, membrane characteristics in oocytes from these groups were similar to those from $0.5-1.9 \mathrm{~mm}$ follicles. The exception related to cumulus cell processes in the largest follicles which were frequently surrounded by a mass of small vesicles (Pl. 3, Fig. 9).

The distribution of mitochondria changed from a restricted peripheral band to a more uniform distribution throughout the cytoplasm (Text-fig. 3). The cortical granules, on the other hand, were primarily located in the region of the plasma membrane (Text-fig. 3; Pl. 3, Figs 8 and 9). Vesicular elements of presumptive endoplasmic reticulum were common among the membrane-bound vesicles.

All the oocytes cultured in the presence of gonadotrophins for $9 \mathrm{~h}$ were in the dictyate stage. Of those cultured for $12 \mathrm{~h}, 10 \%$ remained in the germinal vesicle stage, $46 \%$ were in prometaphase, $39 \%$ in metaphase I and 5\% in telophase I. Of those cultured for $15 \mathrm{~h}, 12 \%$ were in prometaphase, $62 \%$ in metaphase I and $26 \%$ in telophase I.

\section{Preovulatory follicles at late oestrus}

Surrounding the oolemma of most oocytes was a dense layer of particulate material similar to that of the zona pellucida (Pl. 3, Figs 10 and 11). Although some cumulus processes were still present in the zona pellucida, the portions abutting onto the oolemma were generally degenerate (Pl. 3, Fig. 10). They were surrounded by numerous small vesicles.

The mitochondria were evenly distributed throughout the oocyte (Text-fig. 3; Pl. 1, Fig. 3). A count of 135 mitochondria showed that $52 \%$ had developed a curved flap or 'hood' which extended into the cytoplasm (PI. 3, Fig. 11) and were similar to those in bovine oocytes (Senger \& Saake, 1970). The cortical granules were clearly clustered immediately below the plasma membrane (Text-fig. 3; Pl. 3, Figs 10 and 11). The large membrane-bound vesicles still excluded from the periphery of the cell were generally smaller than in previous categories with a mean diameter of about $2.0 \mu \mathrm{m}$ (Pl. 1, Fig. 3).

\section{Discussion}

On the basis of the ultrastructural observations the development of the sheep oocyte may be divided into three phases. (1) A phase of structural change and spatial differentiation as the follicle grows to about $2.0 \mathrm{~mm}$ in diameter. (2) A phase in which little structural alteration is apparent in follicles $>2.0 \mathrm{~mm}$ in diameter in the luteal phase of the cycle and the largest (ovulating) follicle in sheep in early and mid-oestrus. (3) A phase of structural change in late oestrus.

Slender villi were only observed in oocytes of very small follicles. Thereafter they shortened and became thicker with a resultant decrease in surface area which remained constant during subsequent follicular development. These results indicate that the area available for uptake through the plasma membrane may be greatest in small follicles. Direct information on uptake in these follicles is lacking. However, Moor \& Smith (1979) have shown a constant rate of uptake of amino acids into oocytes from follicles of diameter $>3.5 \mathrm{~mm}$, with an increase in uptake occurring only during the second meiotic metaphase.

A constant association between mitochondria and endoplasmic reticulum was observed at all stages of follicular development. Such a feature is common to most mammalian oocytes (Norrevang, 1968). In the sheep the endoplasmic reticulum was initially highly dilated and was temporally related to the presence of extended surface villi, perhaps representing a temporary storage of products produced during the rapid growth phase of the oocyte.

Localization of mitochondria at the periphery of the oocyte has been observed in the rat (Sotelo \& Porter, 1959), hamster (Hadek, 1969) and cow (Fleming \& Saake, 1972), but is 
apparently not found in all species (Zamboni, 1972). In sheep, a tight peripheral band was observed in oocytes from follicles up to $2.0 \mathrm{~mm}$ in diameter. Thereafter they tended to become more dispersed. In the cow (Fleming \& Saake, 1972) a dispersal of mitochondria was associated with the formation of the perivitelline space but no information was given for earlier stages of development.

During late oestrus the mitochondria appeared hooded. Such a structure has been previously reported for cattle, goats and sheep (Senger \& Saake, 1970; Fleming \& Saake, 1972; Russe, 1975). Hooding of mitochondria clearly increases their surface area and may also provide a specific micro-environment to facilitate exchange of metabolic intermediates with the endoplasmic reticulum (Fleming \& Saake, 1972). There appears to be evidence, therefore, for increased mitochondrial activity at this stage of development.

Cortical granules, which were found in all follicles examined, were randomly scattered in small follicles but in the region of the plasma membrane in the larger. However, in late oestrus there was a marked localization immediately beneath the plasma membrane. Szöllösi et al. (1978) found a similar localization in response to LH release, and related this response to a loss of gap junctions between the foot of cumulus processes and the oocyte surface. Unequivocal identification of gap junctions at this location was not possible in the present study, and further study is required to determine the temporal sequence of their breakdown. It is clear, however, that in late oestrus many of the processes have withdrawn and are degenerate, resulting in a reduction in the relationship between the surrounding granulosa cells and the oocyte.

Numerous large vesicles are a characteristic of bovine (Fleming \& Saake, 1972) and ovine oocytes. In the sheep these increase in number during the early stages of follicular development. Information regarding their chemical nature or their derivation is lacking. Small vesicular elements of endoplasmic reticulum are often observed among them and profiles suggestive of fusion or budding of the large vesicles were also noted. However, no clear intermediates between endoplasmic reticulum and the vesicles have been observed and it is possible that the dumb-bell shaped appearance of many of the vesicles is artefactual because of the fragility of the bounding membrane. Russe (1975) described the vesicles as yolk globules, while Fleming \& Saake (1972) termed them granulated vesicles on account of PAS-positive particles within them. In the sheep only flocculent material was present. Similar vesicles have been observed in rabbit (Zamboni \& Mastroianni, 1966a, b; Krauskopf, 1968a, b; Longo \& Anderson, 1969; Gulyas, 1971), ferret (Hadek, 1969) and pig-tailed monkey (Szöllösi, 1972) oocytes, although in these species they were not as frequent as in the sheep. All these studies suggest that the vesicles represent a form of yolk and clearly this is an area which warrants further study.

\section{References}

Dick, E.G., Dick, D.A.T. \& Bradbury, S. (1970) The effect of surface microvilli on the water permeability of single toad oocytes. J. Cell Sci. 6, 451-476.

Fleming, W.N. \& Saake, R.G. (1972) Fine structure of the bovine oocyte from the mature Graafian follicle. J. Reprod. Fert. 29, 203-213.

Gulyas, B. (1971) The rabbit zygote: formation of annulate lamellae. J. Ultrastruct. Res. 35, 112-126.

Hadek, R. (1969) Mammalian Fertilization. Academic Press, New York.

Hay, M.F., Cran, D.G. \& Moor, R.M. (1976) Structural changes occurring during atresia in sheep ovarian follicles. Cell Tiss. Res. 169, 515-529.

Krauskopf, C. (1968a) Elektronenmikroskopische Untersuchungen uber die Struktur der Oocyte und des Z-Zellstadiums beim Kanichen. I. Oocyte. $Z$. Zellforsch. mikrosk. Anat. 92, 275-295.
Krauskopf, C. (1968b) Elektronenmikroskopische Untersuchungen uber die Struktur der Oocyte und des Z-Zellstadiums beim Kanichen. II. Blastomeren. Z. Zellforsch. mikrosk. Anat. 92, 296-312.

Longo, F.J. \& Anderson, E. (1969) Cytological events leading to the formation of the two cell stage in the rabbit: association of the maternally and paternally derived genomes. J. Ultrastruct. Res. 29, 86-118.

Moor, R.M. \& Smith, M.W. (1979) Amino acid transport in mammalian oocytes. Expl Cell Res. 119, 333-341.

Moor, R.M. \& Trounson, A.O. (1977) Hormonal and follicular factors affecting maturation of sheep oocytes in vitro and their subsequent developmental capacity. J. Reprod. Fert. 49, 101-109.

Moor, R.M. \& Warnes, G.M. (1978) Regulation of oocyte maturation in mammals. In Control of 
Ovulation, pp. 159-176. Eds D. B. Crighton, G. R. Foxcroft, N. B. Haynes \& G. E. Lamming. Butterworth, London.

Moor, R.M., Hay, M.F., McIntosh, F.E.A. \& Caldwell, B.V. (1973) Effect of gonadotrophins on the production of steroids by sheep ovarian follicles cultured in vitro. J. Endocr. 58, 599-611.

Moor, R.M., Hay, M.F., Dott, H.M. \& Cran, D.G. (1978) Macroscopic identification and steroidogenic function of atretic follicles in sheep. J. Endocr. 77, 309-318.

Norrevang, A. (1968) Electron microscopic morphology of oogenesis. Int. Rev. Cytol. 23, 114-186.

Russe, I. (1975) Unfertilized sheep eggs. J. Reprod. Med. 14, 200-204.

Sanderson, A.R. \& Stewart, J.S.S. (1961) Nuclear sexing with aceto-orcein. Br. med.J. 21, 1065-1067.

Senger, P.L. \& Saake, R.G. (1970) Unique mitochondria in the bovine oocyte. J. Cell Biol. 46, 405408.
Sotelo, J.R. \& Porter, K.R. (1959) An electron microscopic study of the rat ovum. J. Biophys. Biochem. Cytol. 5, 327-342.

Szöllösi, D. (1972) Changes of some cell organelles during oogenesis in mammals. In Oogenesis, pp. $47-$ 64. Eds J. D. Biggers \& A. W. Schuetz. University Park Press, Baltimore.

Szöllösi, D., Gerard, Y., Menezo, Y. \& Thibault, C. (1978) Permeability of ovarian follicle; corona celloocyte relationship in mammals. Annls Biol, anim. Biochim. Biophys. 18, 511-521.

Zamboni, L. (1972) Comparative studies on the ultrastructure of mammalian oocytes. In Oogenesis, pp. 5-45. Eds J. D. Biggers \& A. W. Schuetz. University Park Press, Baltimore.

Zamboni, L. \& Mastroianni, L. (1966a) Electron microscopic studies on rabbit ova. I. The follicular oocyte. J. Ultrastruct. Res. 14, 95-117.

Zamboni, L. \& Mastroianni, L. (1966b) Electron microscopic studies on rabbit ova. II. The penetrated tubal ovum. J. Ultrastruct. Res. 14, 118-132.

Received 1 October 1979 